Volume 72, Nomor 2, Desember 2020

\title{
Partisipasi Masyarakat Lokal Dalam Pengelolaan Kampung Lawas Maspati, Surabaya
}

\author{
Mochamad Darwin Rahmanto'), Linda Dwi Rohmadiani' ${ }^{2)}$ \\ ${ }^{1,2}$ Perencanaan Wilayah dan Kota, Fakultas Teknik, Universitas PGRI Adi Buana Surabaya \\ Email ${ }^{1}$ : rahmantodarwin@gmail.com, \\ Email $^{2}$ : linda@unipasby.ac.id
}

\begin{abstract}
ABSTRAK
Kampung Lawas Maspati diresmikan sebagai kampung wisata sejarah oleh Pemerintah Kota Surabaya pada tanggal 24 Januari 2016 oleh Wali Kota Surabaya dan PT. Pelindo III. Potensi wisata yang tersedia berupa bangunan kuno, kebun toga dan spot selfie. Penelitian ini bertujuan untuk menganalisis tingkat partisipasi masyarakat dalam pengelolaan kawasan wisata Kampung Lawas Maspati. Metode analisis dalam penelitian ini yaitu deskriptif kualitatif dengan teknik analisis persentase menggunakan tingkat partisipasi Arnstein. Metode pengumpulan data dengan cara dokumentasi dan kuesioner. Hasil penelitian ini menunjukan pengelolaan pariwisata di Kawasan Wisata Kampung Lawas Maspati berdasarkan hasil kuesioner 75\% sudah dilakukan oleh masyarakat dan untuk masyarakat (Citizen Control).
\end{abstract}

Kata Kunci : Kampung Wisata, Partisipasi Masyarakat Lokal

\begin{abstract}
Maspati Lawas Village was inaugurated as a historical tourism village by the Surabaya City Government on January 24, 2016 by the Mayor of Surabaya and PT. Pelindo III. The available tourism potential is in the form of ancient buildings, toga gardens and selfie spots. This study aims to analyze the level of community participation in the management of the tourist area of Maspati Lawas Village. The analytical method in this research is qualitative descriptive with percentage analysis techniques using Arnstein's participation rate. Data collection methods by means of documentation and questionnaires. The results of this study indicate the management of tourism in the Tourism Area of Maspati Lawas Maspati based on the results of a $75 \%$ questionnaire has been done by the community and for the community (Citizen Control).
\end{abstract}

\section{Keywords: Tourism Village, Local Community Participation}

\section{PENDAHULUAN}

Kampung Lawas Maspati masuk dalam wilayah administratif Kelurahan Bubutan dengan luas $\pm 2,45$ Ha. Kampung Lawas Maspati berada di tengah Kota Surabaya dengan jarak \pm 500 meter dari Monumen Tugu Pahlawan. Kawasan wisata Kampung Lawas Maspati berda pada RW 06 yang terdiri dari 5 RT. Kampung Lawas Maspati memiliki daya tarik fisik berupa bangunan bersejarah yang masih utuh, seperti rumah bekas kediaman Raden Sumomiharjo Bangsawan keturunan Kraton Solo yang menjadi mantri kesehatan di kampung Lawas Maspati dan Sekolah Ongko Loro yang merupakan Sekolah Rakyat atau sekolah Dasar, bangunan rumah tua yang merupakan bekas markas tentara yang dibangun pada 1907 dan Pesarean Makam Mbah Buyut Suruh dan terdapat juga kebun TOGA serta area spot foto. Kampung Lawas Maspati jug memiliki daya tarik non fsik yang berupa Musik Patrol dan Tari Remo. Atraksi wisata lainnya seperti kehidupan sehari-hari masyarakat, keramah-tamahan masyarakat, lingkungan yang hijau dan dolanan lawas (Noviyanti et al, 2018) (Larasati, 2017).

Sarana yang tersedia di Kampung Lawas Maspati yaitu sarana peribadatan berupa musholla umum dan juga sudah tersedia toilet umum serta penginapan (home stay). Kampung Maspati dapat diakses melalui Jalan Semarang dan Jalan Bubutan. Kondisi prasarana yang tersedia di Kawasan Wisata Kampung Lawas Maspati yaitu tempat 
sampah dan bank sampah yang digunakan untuk daur ulang sampah, air bersih, drainase dan juga IPAL, namun air dari hasil filtrasi IPAL masih belum dapat diminum, air tersebut dimanfaatkan warga untuk menyiram tanaman, dan mencuci kendaraan. Kampung Lawas Maspati memiliki jumlah penduduk 1.350 jiwa dan 350 Kepala Keluarga (KK) dengan kepadatan 552 jiwa/Ha. Tingkat pendidikan masyarakat Kampung Lawas Maspati 38, 25\% tamatan SLTA dengan mata pencaharian masyarakat Kampung Lawas Maspati $67 \%$ sebagai wirausaha.

Kampung Lawas Maspati memiliki beberapa karakteristik sosial budaya yaitu Festival Kampung Lawas Maspati yang di akhiri dengan pengajian umum, Forum Kreatif Religius dan Berbudi (KEREB), Pembinaan Asuhan Mandiri (ASMAN) melalui pemanfaatan Tanaman Obat Keluarga (TOGA). Pengelolaan wisata Kampung Lawas Maspati ini dikepalai oleh Ketua RW 06 dan dibantu oleh para Ketua RT serta masyarakat Kampung Lawas Maspati. Pengurus Kampung Lawas Maspati berwenang dan bertanggung jawab atas proses managerial pengelolaan wisata (Sanggel, 2019).

Promosi wisata Kampung Lawas Maspati menggunkan media online yang memanfaatkan media sosial antara lain: facebook, Instagram, web site dan blogspot, selain mengunkan media online promosi wisata Kampung Lawas Maspati juga menggunakan media cetak yang berupa brosur dan surat kabar koran. Penggunaan lahan kawasan wisata Kampung Lawas Maspati dengan luas $2,45 \mathrm{Ha}$ dan terbagi menjadi 4 jenis penggunaan lahan berupa bangunan kuno, sarana wisata, Ruang Terbuka Hijau (RTH) dan rumah. Penggunaan lahan Kampung Lawas Maspati sebagian besar digunakan untuk rumah yaitu sebesar 2,29 $\mathrm{Ha}$ $(93,46 \%)$ seperti Gambar 1.

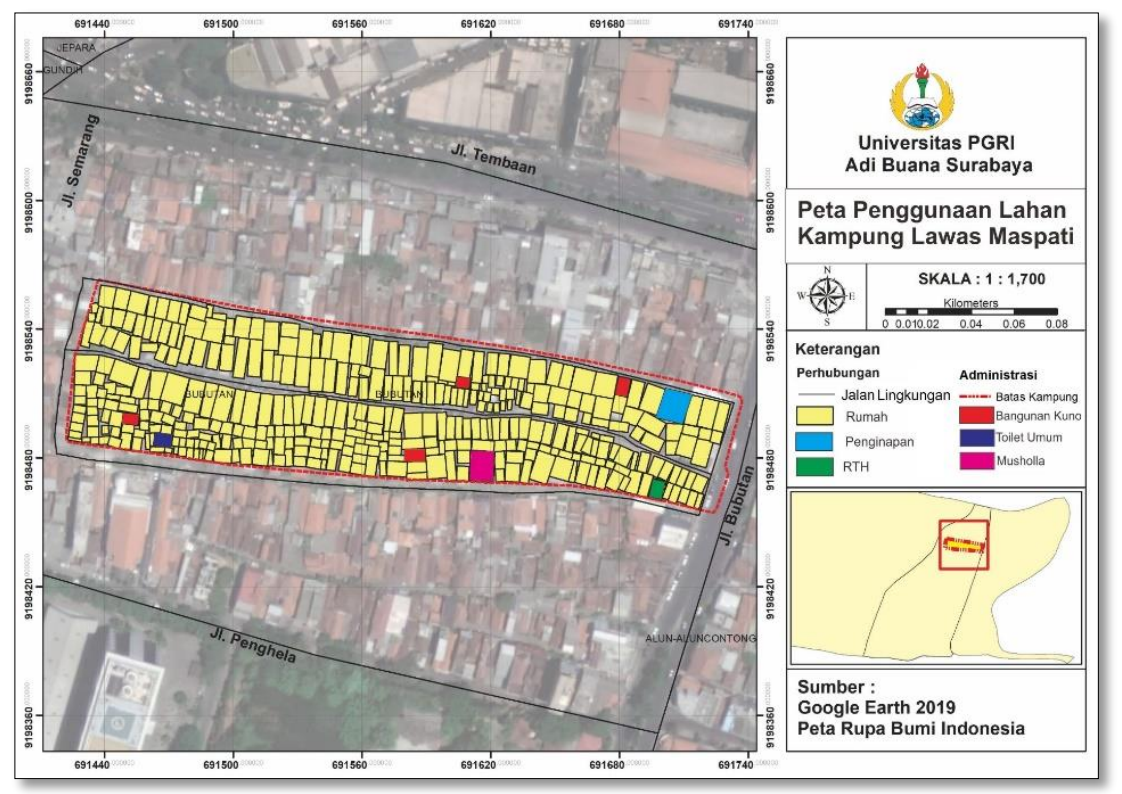

\section{Gambar 1. Peta Penggunaan Lahan Kampung Lawas Maspati}

Tujuan penelitian adalah untuk menganalisis tingkat partisipasi masyarakat dalam pengelolaan kawasan wisata Kampung Lawas Maspati berdasarkan 8 tingkatan partisipasi Arstein (1969) dalam Permatasari et. al, (2018). Pengembangan wisata Kampung Lawas Maspati dapat meningkatkan

kesejahteraan masyarakat, dan memiliki efek „keberlanjutan ${ }^{\text {"e }}$ atau jangka panjang (Sanggel, 2019).

\section{METODE PENELITIAN}

Metode pengumpulan data dengan cara dokumentasi dan kuesioner sedangkan metode analisis yang 
digunakan yaitu deskriptif kualitatif dengan teknik analisis persentase menggunakan tingkat partisipasi Arnstein. Rumus untuk menghitung persentase menggunakan rumus sebagai berikut (Arikunto, 2010):

$$
P=\frac{n}{N} \times 100 \%
$$

Keterangan:

$\mathrm{P}=$ Persentase $(\%)$

$\mathrm{n}=$ Skor empirik (Skor yang diperoleh)
$\mathrm{N}=$ Skor Ideal untuk setiap item pertanyaan/Jumlah responden $=78$

Analisis tingkat partisipasi menggunakan indikator tingkat partisipasi masyarakat menurut Arnstein yang dijelaskan pada Tabel 1, indikator tersebut digunakan sebagai alternatif pilihan untuk mengisi Instrument analisis tingkat partisipasi masyarakat. Pengertian level partisipasi masyarakat menurut Arnstein dijelaskan pada Tabel 2.

Tabel 1. Tingkat Partisipasi Masyarakat Menurut Arnstein (1969)

\begin{tabular}{clccc}
\hline No. & \multicolumn{1}{c}{ Level } & Pengetahuan & Manfaat & Kehadiran \\
\hline 8. & Kontrol masyarakat & Tahu & Tahu & Inisiatif hadir \\
\hline 7. & Pendelegasian kekuasaan & Tahu & Tahu & Inisiatif hadir \\
\hline 6. & Kemitraan & Tahu & Tahu & Inisiatif hadir \\
\hline 5. & Penentraman & Tahu & Tahu & Sukarela \\
\hline 4. & Konsultasi & Tahu & Tahu & Sukarela \\
\hline 3. & Pemberitahuan & Tidak tahu & Tahu & Sukarela \\
\hline 2. & Terapi & Tidak tahu & Tahu & Terpaksa \\
\hline 1. & Manipulasi & Tidak tahu & Tidak tahu & Terpaksa \\
\hline
\end{tabular}

Sumber : Arnstein, (1969) dalam Permatasari et. al, (2018)

Tabel 2 Pengertian Level Partisipasi Masyarakat Menurut Arnstein

\begin{tabular}{|c|c|c|}
\hline No. & Level & Penjelasan \\
\hline 8. & $\begin{array}{l}\text { Citizen control } \\
\text { (Kontrol masyarakat) }\end{array}$ & $\begin{array}{l}\text { Masyarakat memiliki pengetahuan mengenai pengelolaan } \\
\text { wisata (hingga pemeliharaan, promosi wisata, sosialisasi } \\
\text { dalam penyelenggaraan) dan berinisiatif hadir dalam kegiatan } \\
\text { karena memiliki kekuasaan penuh }\end{array}$ \\
\hline 7. & $\begin{array}{l}\text { Delegated power } \\
\text { (Pendelegasian } \\
\text { Kekuasaan) }\end{array}$ & $\begin{array}{l}\text { Masyarakat memiliki pengetahuan mengenai pengelolaan } \\
\text { wisata mulai dari tahap perencanaan, pelaksanaan hingga } \\
\text { kelembagaan dan berinisiatif hadir karena memiliki } \\
\text { kewenangan membuat keputusan. }\end{array}$ \\
\hline 6. & $\begin{array}{l}\text { Partnership } \\
\text { (Kemitraan ) }\end{array}$ & $\begin{array}{l}\text { Masyarakat memiliki pengetahuan mengenai pengelolaan } \\
\text { wisata, mengetahui manfaat pariwisata bagi ekonomi, dan } \\
\text { berinisiatif hadir dalam kegiatan setelah adanya kesepakatan } \\
\text { bersama. }\end{array}$ \\
\hline 5. & $\begin{array}{l}\text { Placation } \\
\text { (Penentraman) }\end{array}$ & $\begin{array}{l}\text { Masyarakat memiliki pengetahuan mengenai pengelolaan } \\
\text { wisata (cara mengelola wisata), mengetahui manfaat } \\
\text { pariwisata bagi ekonomi, dan hadir dalam kegiatan secara } \\
\text { sukarela. }\end{array}$ \\
\hline 4. & $\begin{array}{l}\text { Consultation } \\
\text { (Konsultasi) }\end{array}$ & $\begin{array}{l}\text { Masyarakat sudah mulai memiliki pengetahuan mengenai } \\
\text { pariwisata, mengetahui manfaat pariwisata bagi ekonomi, dan } \\
\text { hadir dalam kegiatan secara sukarela. }\end{array}$ \\
\hline 3. & $\begin{array}{l}\text { Informing } \\
\text { (Pemberian informasi) }\end{array}$ & $\begin{array}{l}\text { Masyarakat tidak memiliki pengetahuan mengenai pariwisata, } \\
\text { mengetahui manfaat pariwisata bagi ekonomi, dan hadir } \\
\text { dalam suatu kegiatan secara sukarela. }\end{array}$ \\
\hline 2. & $\begin{array}{l}\text { Therapy } \\
\text { (Terapi) }\end{array}$ & $\begin{array}{l}\text { Masyarakat tidak memiliki pengetahuan mengenai pariwisata, } \\
\text { mengetahui manfaat pariwisata, dan hadir dalam suatu } \\
\text { kegiatan karena terpaksa. }\end{array}$ \\
\hline
\end{tabular}


Volume 72, Nomor 2, Desember 2020

\begin{tabular}{lll}
\hline No. & \multicolumn{1}{c}{ Level } & \multicolumn{1}{c}{ Penjelasan } \\
\hline 1. & $\begin{array}{l}\text { Manipulation } \\
\text { (Manipulasi) }\end{array}$ & $\begin{array}{l}\text { Masyarakat tidak memiliki pengetahuan mengenai pariwisata, } \\
\text { tidak tahu manfaat pariwisata, dan hadir dalam suatu kegiatan } \\
\text { karena terpaksa. }\end{array}$ \\
\hline Sumber : & Arnstein, (1969) dalam Permatasari et. al, (2018)
\end{tabular}

3. HASIL DAN PEMBAHASAN

A. Tingkat Partisipasi Masyarakat Dalam Pengelolaan Bangunan Kuno

Tingkat partisipasi masyarakat dalam pengelolaan bangunan kuno tergolong tinggi dengan nilai persentase terbanyak yaitu pada tingkat Citizen Control (kontrol masyarakat) dengan nilai persentase sebesar 88\%. Arnstein dalam Raharjana (2012), bentuk partisipasi ini mencirikan masyarakat yang sudah mandiri dimana mampu mengelola daerah atau desa dengan manajemen sendiri tanpa intervensi dari pihak lain. Bentuk partisipasi yang dilakukan masyarakat berupa partisipasi tenaga dan harta benda. Terbukti dengan adanya inisiasi dari masyarakat sendiri untuk merawat dan memelihara bangunan-bangunan kuno dengan baik sampai saat ini, sehingga dapat menjadi salah satu daya tarik wisata Kampung Lawas Maspati. Bangunan lawas tersebut dimanfaatkan sebagai daya tarik wisata dan amenitas (Sanggel, 2019). Diagram nilai persentase tingkat partisipasi masyarakat dalam pengelolaan bangunan kuno dapat dilihat pada Gambar 2.

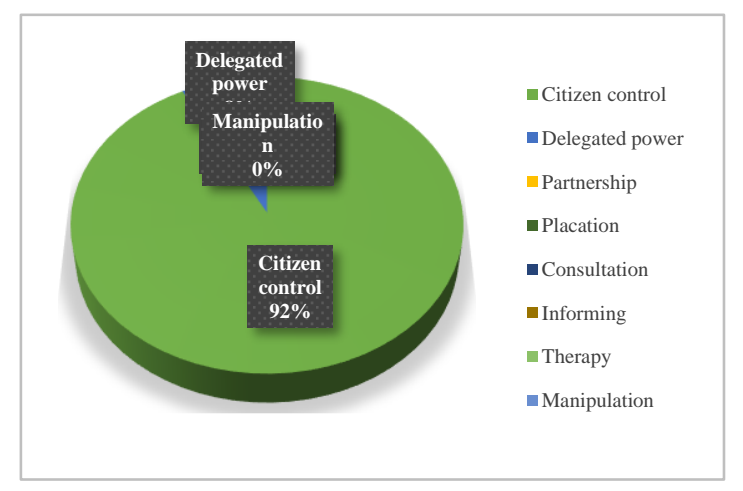

\section{Gambar 2. Persentase Tingkat Partisipasi Masyarakat Dalam Pengelolaan Bangunan Kuno}

\section{B. Tingkat Partisipasi Masyarakat Dalam Pengelolaan Kebun TOGA}

Tingkat partisipasi masyarakat dalam pengelolaan kebun TOGA persentase terbesar yaitu berada pada tingkat Citizen Control (kontrol masyarakat) sebesar 91\%. Bentuk partisipasi yang dilakukan masyarakat berupa partisipasi pikiran dan tenaga. Terbukti dengan adanya kebun TOGA yang sampai saat ini tumbuh subur karena dirawat atas inisiasi masyarakat setempat dan dimanfaatkan sebagai olahan makanan dan minuman untuk dijadikan oleh-oleh bagi wisatawan sehingga memberikan nilai ekonomis bagi masyarakat. Diagram nilai persentase tingkat partisipasi masyarakat dalam pengelolaan kebun TOGA dapat dilihat pada Gambar 3.

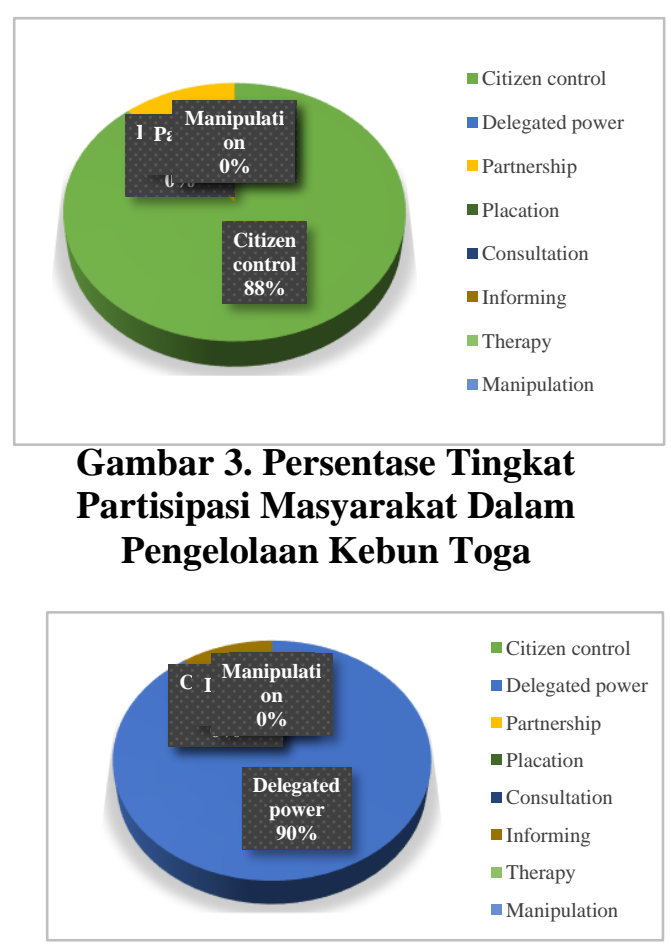


WAHANA

Volume 72, Nomor 2, Desember 2020

\section{Tingkat Partisipasi Masyarakat} Dalam Pengelolaan Area Spot Foto

Tingkat partisipasi masyarakat dalam pengelolaan area spot foto di kawasan wisata Kampung Lawas Maspati diketahui persentase terbesar yaitu berada pada tingkat Citizen Control (kontrol masyarakat) sebesar 92\%. Bentuk partisipasi yang dilakukan masyarakat berupa partisipasi pikiran, tenaga dan harta benda. Terbukti dengan adanya beberapa area spot foto 2 dan 3 dimensi yang dibuat atas inisiasi masyarakat sendiri dan masih terawat sampai saat ini sehingga menjadi suatu daya tarik wisata. Diagram nilai persentase tingkat partisipasi masyarakat dalam pengelolaan area spot foto dapat dilihat pada Gambar 4.

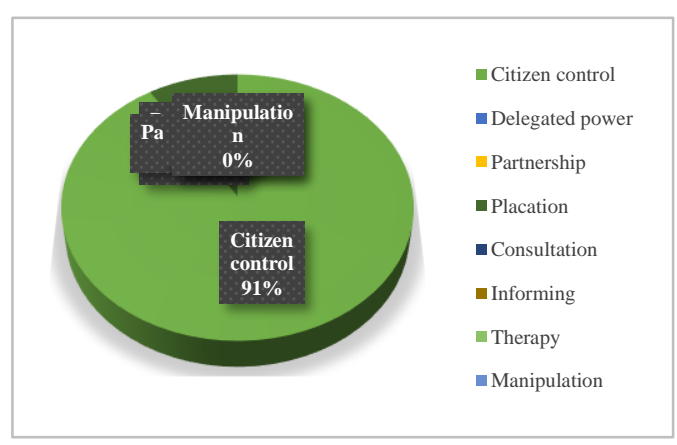

Gambar 4. Persentase Tingkat

Partisipasi Masyarakat Dalam Pengelolaan Area Spot Foto

\section{Tingkat Partisipasi Masyarakat \\ Dalam Pengelolaan Pertunjukan \\ Musik dan Tarian Tradisional}

Tingkat partisipasi masyarakat dalam pengelolaan pertunjukan musik dan tarian tradisional diketahui nilai persentase terbesar yaitu berada pada tingkat Delegated Power (pendelegasian kekuasaan) sebesar 90\%. Partisipasi dalam dalam pengelolaan pertunjukan musik dan tarian tradisional belum Citizen Control karena pertunjukan ini hanya dilakukan pada pengunjung yang sebelumnya telah melakukan reservasi saja. Diagram nilai persentase tingkat partisipasi masyarakat pengelolaan pertunjukan musik dan tarian tradisional dapat dilihat pada Gambar 5.

Gambar 5. Persentase Tingkat

Partisipasi Masyarakat Dalam

Pengelolaan Pertunjukan Musik dan Tarian Tradisional

\section{E. Tingkat Partisipasi Masyarakat \\ Dalam Pengelolaan Sarana \\ Peribadatan}

Tingkat partisipasi masyarakat dalam pengelolaan sarana peribadatan diketahui persentase terbesar yaitu pada tingkat Citizen Control (kontrol masyarakat) dengan nilai persentase sebesar $96 \%$. Bentuk partisipasi yang dilakukan masyarakat berupa partisipasi tenaga. Terbukti dengan terpeliharanya sarana peribadatan yang berupa musholla umum sehingga dapat digunakan untuk beribadah bagi wisatawan dan masyarakat setempat Diagram nilai persentase tingkat partisipasi masyarakat dalam pengelolaan sarana peribadatan dapat dilihat pada Gambar 6.

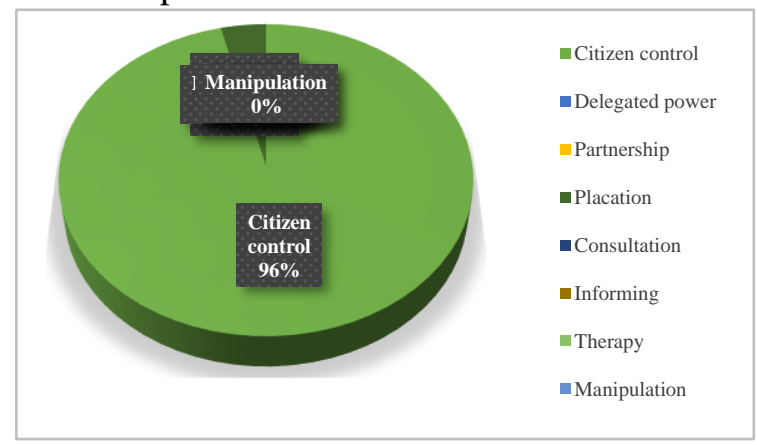

Gambar 6. Persentase Tingkat

Partisipasi Masyarakat Dalam

Pengelolaan Sarana Peribadatan

\section{F. Tingkat Partisipasi Masyarakat Dalam Pengelolaan Sarana Toilet Umum}

Tingkat partisipasi masyarakat dalam pengelolaan sarana toilet umum persentase terbesar yaitu berada pada tingkat Placation (penentraman) sebesar 83\%. Menurut Arnstein dalam Raharjana (2012), bentuk partisipasi ini 


\section{WAHANA}

Volume 72, Nomor 2, Desember 2020

masyarakat diberikan suatu kekuasaan yang sah dan dapat membuat rencana kegiatan sendiri yang tentunya melalui persetujuan pemerintah, hal ini seperti dibentuknya organisasi, badan ataupun lembaga di desa oleh pemerintah. Wisatawan masih menggunakan toilet milik warga atau toilet mushola. Jika ada kegiatan besar, warga memperoleh bantuan dari pemerintah kota (Noviyanti et al, 2018). Diagram nilai persentase tingkat partisipasi masyarakat dalam pengelolaan sarana toilet umum dapat dilihat pada Gambar 7.

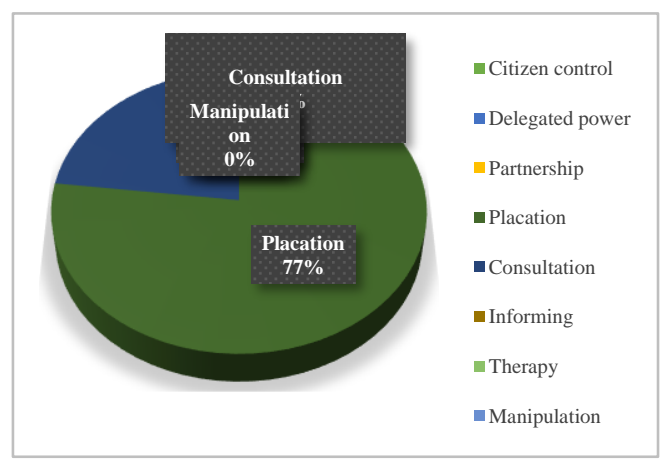

\section{Gambar 7. Persentase Tingkat Partisipasi Masyarakat Dalam Pengelolaan Sarana Toilet Umum}

\section{G. Tingkat Partisipasi Masyarakat Dalam Pengelolaan Sarana Penginapan (Home Stay)}

Tingkat partisipasi masyarakat dalam pengelolaan sarana penginapan (home stay) persentase terbesar yaitu berada pada tingkat Placation (penentraman) sebesar 77\%. Kampung Lawas Maspati telah tersedia penginapan dan restauran untuk memudahkan wisatawan wisatawan untuk beristirahat (Noviyanti et al, 2018). Diagram nilai persentase tingkat partisipasi masyarakat dalam pengelolaan sarana penginapan (home stay) dapat dilihat pada Gambar 8.

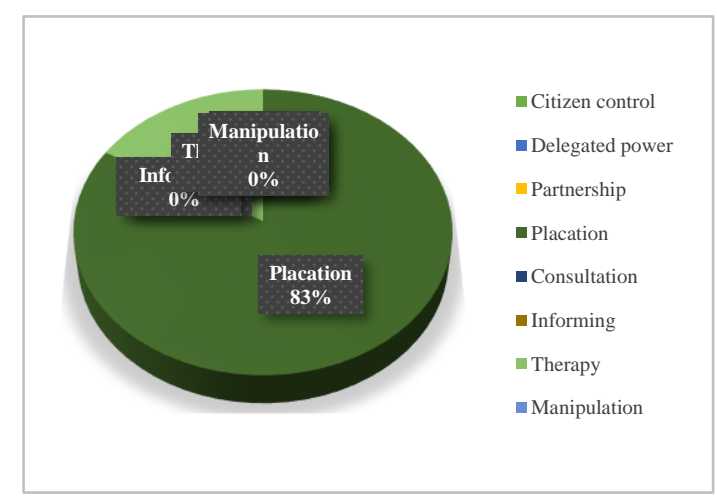
Gambar 8. Persentase Tingkat
Partisipasi Masyarakat Dalam
Pengelolaan Pengelolaan Sarana Penginapan (Home Stay)

\section{H. Tingkat Partisipasi Masyarakat Dalam Pengelolaan Prasarana Persampahan}




\begin{abstract}
Tingkat partisipasi masyarakat dalam pengelolaan prasarana persampahan diketahui persentase terbesar yaitu berada pada tingkat Citizen Control (kontrol masyarakat) dengan nilai persentase yaitu $97 \%$. Bentuk partisipasi yang dilakukan masyarakat berupa partisipasi tenaga dan pikiran. Terbukti dengan adanya sistem pengelolaan sampah yang dilakukan masyarakat berupa kegiatan daur ulang sampah untuk dijadikan sesuatu yang dapat menjadi nilai ekonomis bagi masyarakat. Bentuk partisipasi dalam pengelolaan lingkungan adalah kegiatan kerja bakti yang dilakukan oleh masyarakat setiap bulan (Imanah \& Ma'ruf, 2018). Diagram nilai persentase tingkat
\end{abstract}

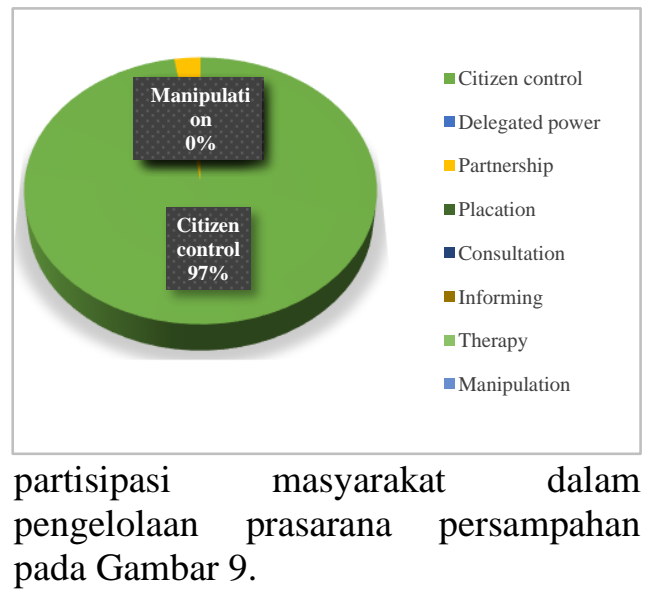

\section{Gambar 9 Persentase Tingkat Partisipasi Masyarakat Dalam Pengelolaan Prasarana Persampahan}

\section{Tingkat Partisipasi Masyarakat Dalam Pengelolaan Prasarana Air Bersih}

Tingkat partisipasi masyarakat dalam pengelolaan air bersih tergolong tinggi karena seluruh masyarakat yang berada pada kawasan Wisata Kampung Lawas Maspati sudah menggunakan sumber air bersih dari PDAM. Nilai persentase yaitu $100 \%$ dan berada pada tingkat Citizen Control (kontrol masyarakat). Bentuk partisipasi masyarakat menurut hasil penelitian
Imanah dan Ma'ruf (2018) berupa sumbangan ide, tenaga, harta benda,

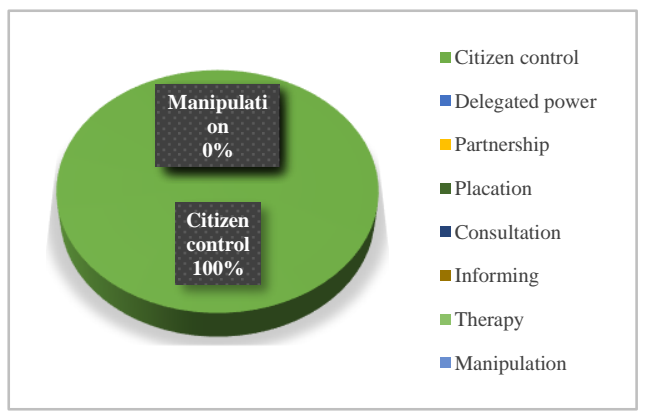

kemahiran dan ketrampilan serta sosial. Diagram nilai persentase tingkat partisipasi masyarakat dalam pengelolaan prasarana persampahan dapat dilihat pada Gambar 10.

\section{Gambar 10. Persentase Tingkat \\ Partisipasi Masyarakat Dalam Pengelolaan Prasarana Air Bersih}

\section{J. Tingkat Partisipasi Masyarakat Dalam Pengelolaan Prasarana Drainase dan IPAL}

Tingkat partisipasi masyarakat dalam pengelolaan prasarana sampah persentase terbesar yaitu berada pada tingkat Citizen Control (kontrol masyarakat) sebesar 90\%. Bentuk partisipasi yang dilakukan masyarakat berupa partisipasi pikiran dan tenaga. Terbukti dengan adanya ide dari masyarakat untuk membuat sistem Instalasi Pengelolaan Air Limbah (IPAL) dan drainase yang kondisinya sangat terawat karena masyarakat setempat setiap satu bulan sekali melakukan kerja bakti untuk membersihkan lingkungan salah satunya membersihkan drainase. Diagram nilai persentase tingkat partisipasi masyarakat dalam pengelolaan prasarana drainase dan IPAL dapat dilihat pada Gambar 11. 
Volume 72, Nomor 2, Desember 2020

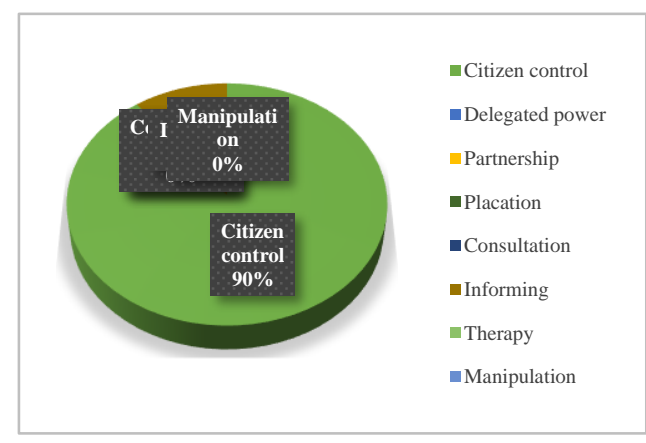

Gambar 11. Persentase Tingkat Partisipasi Masyarakat Dalam Pengelolaan Prasarana Drainase dan IPAL

\section{K. Tingkat Partisipasi Masyarakat Dalam Promosi Wisata Melalui Media Cetak}

Tingkat partisipasi masyarakat dalam promosi wisata melalui media diketahui persentase terbesar yaitu berada pada tingkat Citizen Control (kontrol masyarakat) sebesar $91 \%$. Bentuk partisipasi yang dilakukan masyarakat berupa partisipasi pikiran dan tenaga. Terbukti dengan adanya inisiasi masyarakat yang membuat brosur atau katalog wisata Kampung Lawas Maspati yang disebarkan ke masyarakat luas sebagai media promosi wisata Diagram nilai persentase tingkat partisipasi masyarakat dalam promosi wisata melalui media cetak dapat dilihat pada Gambar 12.

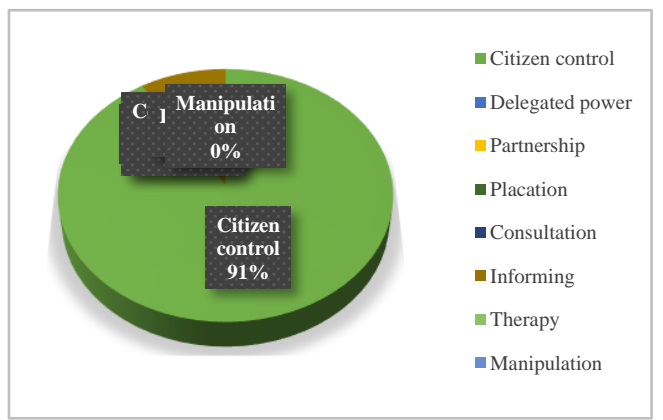

\section{Gambar 12. Persentase Tingkat Partisipasi Masyarakat Dalam Promosi Wisata Melalui Media Cetak}

\section{Tingkat Partisipasi Masyarakat Dalam Promosi Wisata Melalui Media Online}

Tingkat partisipasi masyarakat dalam promosi media online tergolong tinggi karena sebagian besar masyarakat yang berada pada kawasan Wisata Kampung Lawas Maspati sudah mengenal teknologi dan media sosial, melaui media sosial masyarakat lebih mudah untuk mempromosikan wisata. Nilai persentase tingkat partisipasi masyarakat dalam promosi wisata melalui media online sebesar $100 \%$ dan berada pada tingkat Citizen Control (kontrol masyarakat). Diagram nilai persentase tingkat partisipasi masyarakat dalam promosi wisata melalui media online dapat dilihat pada Gambar 13.

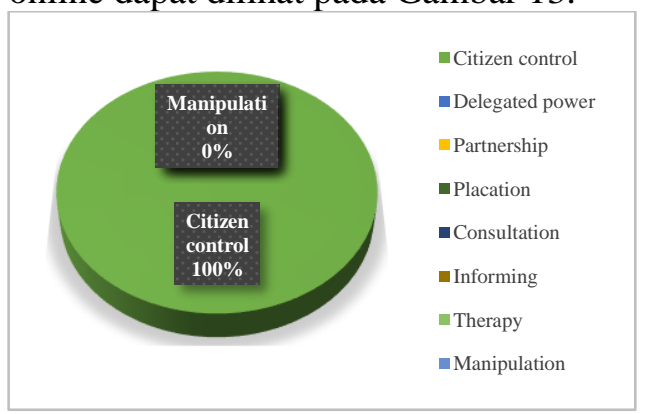

Gambar 13. Persentase Tingkat Partisipasi Masyarakat Dalam Promosi Wisata Melalui Media Online

\section{KESIMPULAN}

Pengelolaan wisata di Kawasan Wisata Kampung Lawas Maspati berdasarkan hasil kuesioner $75 \%$ sudah dilakukan oleh masyarakat dan untuk masyarakat (Citizen Control) dalam bentuk pengelolaan bangunan kuno, pengelolaan kebun TOGA, partisipasi 
Volume 72, Nomor 2, Desember 2020

dalam pengelolaan area spot foto, partisipasi dalam pengeloaan sarana peribadatan, partisipasi dalam pengelolaan prasarana persampahan, pengelolaan prasarana air bersih, pengelolaan prasarana drainase dan IPAL serta promosi wisata melalui media cetak dan media online.

\section{DAFTAR PUSTAKA}

Arikunto, S. (2010). Prosedur Penelitian Suatu Pendekatan Praktik. Jakarta: PT. Rineka Cipta.

Imanah, L. N. \& Ma'ruf, M. F. (2018). Partisipasi Masyarakat Dalam Melestarikan Situs Sejarah Kota Surabaya Melalui Wisata Edukasi Berbasis Masyarakat Di Kampung Lawas Maspati Surabaya. Jurnal Mahasiswa Unesa Vol. 6 No. 1.

Larasati, N. K. R. (2017). Strategi Pengembangan Pariwisata Budaya Yang Berkelanjutan Pada Kampung Lawas Maspati Kota Surabaya. Tugas Akhir Departemen Perencanaan Wilayah dan Kota ITS Surabaya.

Noviyanti, U.D.E., Aly, M.N. \& Fiatiano, E. (2018). Potensi Pengembangan Kampung Wisata Lawas Maspati Sebagai Destinasi Wisata Baru Surabaya. Jurnal Sains Terapan Pariwisata Vol. 3 No. 2.

Permatasari, C., Soemirat, J., \& Ainun, S. (2018). Identifikasi Tingkat Partisipasi Masyarakat dalam Pengelolaan Air Bersih di Kelurahan Cihaurgeulis. Jurnal Online Teknik Lingkungan Itenas Vol. 1 No. 6.

Raharjana, D. T. (2012). Membangun Pariwisata Bersama Rakyat: Kajian Partisipasi Lokal Dalam Membangun Desa Wisata di Dieng Plateau. Jurnal Kawistara Vol. 2 No. 3.

Sanggel, A. I. I. (2019). Inovasi Sosial Masyarakat Dalam Pendekatan

\author{
Asset-Based Community \\ Development di Kampung Lawas \\ Maspati Kecamatan Bubutan Kota \\ Surabaya. Tesis Jurusan \\ Administrasi Negara Fakultas Ilmu \\ Sosial dan Ilmu Politik Universitas \\ Airlangga.
}

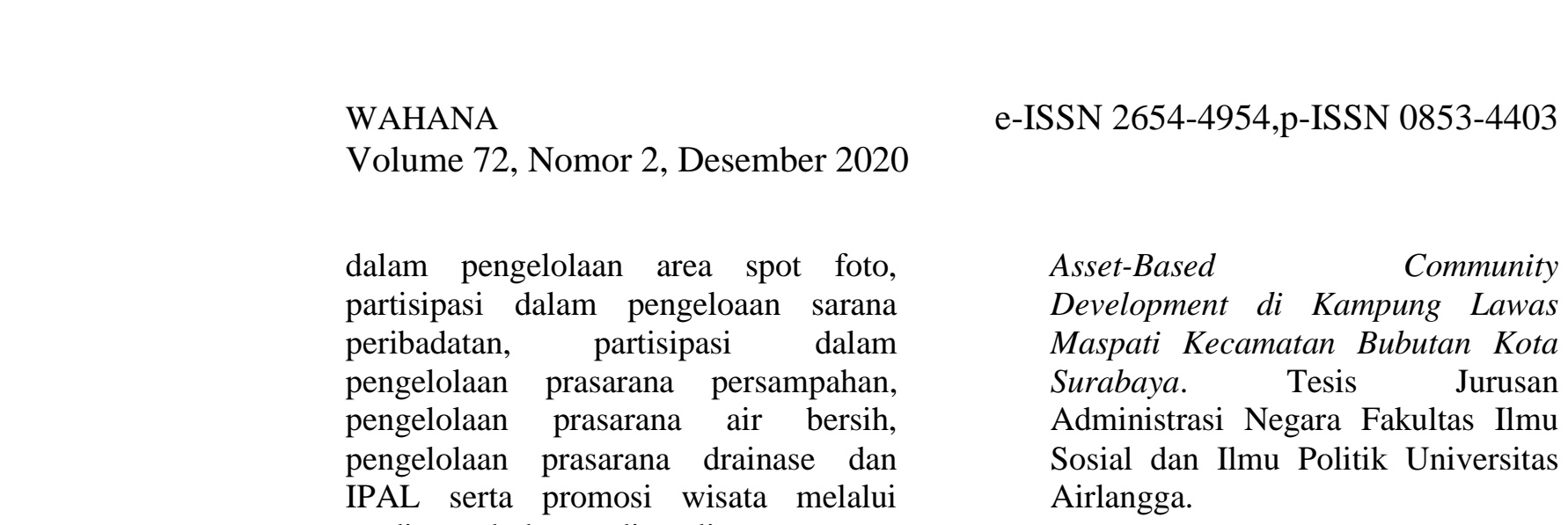

